\title{
STRANPUTICE SA GLOBALIZACIJOM*
}

\author{
Goran Budžak** \\ Institut za političke studije - Beograd \\ Jovo Marković***
}

radu se analizira odnos globalizacije, globalizma, liberalnog

kapitalizma i njihov uticaj na suverenitet i ekonomiju nacionalno ustrojene države.

Ključne reči: prevare, globalizacija, neoliberalizam, nacija, država, ekonomija, međunarodno pravo, hegemonizam

\section{Uvod}

Naučna teorija o značenju jezika i jezičkih izraza (etimologija) nas uči da su termini imena za pojmove, a pojmovi imena za stvarnost. Kako onda objasniti zdravom razumu da su SAD bile i ostale „centar demokratije u svetu“ i da možemo utemeljeno da govorimo o evrointegracijama ili pak pridruživanju novih NATO članica organizacije, a ne o procesima asimilacije? Zbog čega se jedan politički proces koji je po svim bitnijim elementima, tj. osnovnim svojstvima asimilacija naziva integracijom? Uzgred, i kada govorimo o pokliču Zapada i „prodoru na Istok“ zašto zaboraviti da su u istoriji Evrope postojali i prodori na Zapad kako konjanika iz azijskih stepa tako i muslimanskih osvajača iz Male Azije? Hronološki i sintetički iskazano u bližoj i daljoj istoriji planovi o proširenju na Istok, uglavnom, su poticali iz Rima, Beča, Pariza, Berlina, a danas iz Vašingtona i Brisela.

Imperijama se pišu ode i dodeljuju nagrade, često kada ih one uopšte ne zaslužuju, ali tendencije koje dovode do lokalnih i svetskih kriza najčešće smanjuju njihovu moć, a u procesima kada one menjaju svoj oblik ili čak prestaju da postoje. Evropska unija je najbliži strateški saradnik SAD. Od svog osnivanja do danas ona je prošla više faza, od Evropske zajednice za ugalj i čelik 1952. godine, preko Rimskog sporazuma 1957. kada je promenila naziv u Evropsku ekonomsku zajednicu (EEZ), do Mastrihta 1992. godine i sporazuma o Evropskoj uniji (EU). Bez sumnje je da se proširila u ekonomsku, monetarnu i spoljnopolitičku zajednicu od 12-28 članica. Naravno, nisu sve države Centralne i Jugoistočne Evrope pod istim uslovima primljene u EU, dok je većina pridošlica ipak prvo primljena u NATO vojnu alijansu. U završnoj strategiji proširenja za EU pominju se države Zapadnog Balkana, Srbija, Crna Gora, BiH, BJRM, Albanija i samoproklamovana država Kosovo.

\footnotetext{
* Ovaj rad je nastao kao rezultat rada na projektu „Demokratski i nacionalni kapaciteti Srbije u procesu međunarodnih integracija" (br. 179009), koji finansira Ministarstva prosvete, nauke i tehnološkog razvoja Republike Srbije.

** Dr Goran Budžak je naučni saradnik Instituta za političke studije.

*** Mr Jovo Marković je politikolog i samostalni istraživač.
} 
Međutim, u novijoj istoriji ove zajednice jedan događaj deluje bar protivrečno ako ne apsurdno. To je dodeljivanje Nobelove nagrade za mir 2014. godine. Tim povodom u obrazloženju Nobelovog komiteta se kaže da je ona nagrađena zbog šestodecenijskog doprinosa unapređenju mira i pomirenja, demokratije i ljudskih prava u Evropi i da je to potpuno u skladu sa kriterijumima koje je Alfred Nobel istakao u njegovom testamentu 1895. godine. Zatim se konstatuje da ova međunarodna zajednica prolazi kroz tešku ekonomsku krizu, potresaju je socijalni nemiri, a danas i dezintegracioni procesi. Međutim, Nobelov komitet želi da se usredsredi na ono što smatra najvažnijim u EU, a to je njena mobilizatorska uloga, kojom utiče da se Evropa od kontinenta rata pretvori u kontinent mira i tako postane bratstvo među narodima. Ovakve tvrdnje Nobelovog komiteta deluju bar neutemeljeno kada se ima u vidu šta se sve dešavalo nedavno na kraju 20. veka baš u procesima razbijanja jugoslovenske države.

Građaninu Evrope ostaje da se pita da li je reč o ovoj istoj Evropi, pogotovo Evropskoj uniji?!

\section{Teorija modernizacije}

U svojim osnovnim aspektima teorija globalizacije se nadovezuje na teoriju modernizacije, koja je nastala posle Drugog svetskog rata sa dekolonizacijom bivših kolonija. Strah od prodora komunizma u zemlje Trećeg sveta u novonastalim okolnostima trebalo je otkloniti tako što je dekolonizirane zemlje trebalo usmeriti da krenu modernizacijskim putem, tj. putem kojim su odavno krenule zemlje na Zapadu, posebno SAD kao najuspešniji model takvog razvoja. Raspad kolonijalnih imperija u Africi, Aziji i Južnoj Americi je uticao ne samo da počnu traganja za novim društvenim, ekonomskim i političkim rešenjima već i da na svetskoj političkoj sceni otpočne borba za prevlast nad ovim zemljama.

Mnogobrojne i različite definicije modernizacije su se menjale i razvijale tokom vremena. U početku modernizacija se uglavnom shvata kao evolutivni proces transformacije tradicionalnih agrarnih u moderna industrijska društva. Po klasičnoj teoriji modernizacije postoji samo jedan put razvoja koji se odvija u više etapa, a mehanizam promena se dešava putem strukturalno-funkcionalne diferencijacije, koja se razvija na tehnološko-industrijskom razvoju. Više je nego uočljivo da u ovim modernizacijskim koncepcijama dominira nemarksistička dimenzija razvoja. Kao i kod većine drugih teorija tokom daljeg razvoja shvatanje modernizacije se menjalo. Tako je po Vineru ${ }^{\uparrow}$ modernizacija jedinstvena $i$ celovita promena na nivou globalnog društva, a po Epteru "oblik društvene promene" i „poseban slučaj društvenog razvitka“. Modernizacija podrazumeva društveni sistem osposobljen za inovacije, diferenciranu socijalnu strukturu, zastupljenost intelektualnih i tehničkih elemenata u društvenom životu, itd. ${ }^{3}$ Vremenom teorija modernizacije uglavnom je postala sinonim za vesternizaciju što znači da označava procese koji se vremenski i prostorno odnose na SAD i druge zapadne zemlje.

\footnotetext{
${ }^{1}$ Weiner M., Modernization, New York, London: Basic Books, pp. 3.

${ }^{2}$ Apter D. E., „Political systems and Development Change“, in: R. T. Hold and J. E. Turner eds., The Methodology of Comparative Research, New York: The Free Press, 1970, pp. 151-153.

${ }^{3}$ Isto.
} 


\section{Nacionalna država i nacionalna ekonomija}

Danas je globalizacijska invazija u toj meri uzela maha da je mnogi shvataju kao neminovnost čijoj agresiji je najbolje da se svi subjekti i individualni i kolektivni sklanjaju s puta. Postala je česta pojava da se legitimitet, narodi i nacionalne države sve manje traže u tradicionalnim demokratskim izborima već u novim poznatim međunarodnim centrima, u centrima ekonomske i političke moći. Da li je i u kojoj meri ovaj trend u međunarodnim odnosima informativno-politički potpomognut ilustruju i reči Sergeja Kara-Murze „vera u mističnu snagu protivnika parališe volju za otporom“.

Generalno, globalizacija baš nikako ne doprinosi razvoju slabih ekonomija već samo stalno uvećava razlike između bogatih i siromašnih. Poznato je i da neoliberalni kapitalizam teži slobodama, ali ne individualnim i nacionalnim već, pre svega, slobodama tržišta. Neophodno je imati u vidu da je globalizacija prevashodno ekonomski proces, a tek onda politički, informacioni, kulturni, itd.

$\mathrm{U}$ ovim procesima pojam nacionalna ekonomija gubi svoj osnovni smisao i značenje, jer u ovim tendencijama trend je da nacionalna ekonomija bude sve manje povezana sa sopstvenom državom, nacijom, tj. osnovnim potrebama njenih građana. Glavni ekonomski subjekt postaju transnacionalne kompanije (TNK), kojima na putu ima sve manje međunarodnih prepreka, a koje razmeštaju njihovu proizvodnju i plasiraju njihove proizvode samo tamo gde je za njih najpogodnije, drugim rečima najprofitabilnije.

Momir Bulatović u njegovoj knjizi „Ekonomija i demokratija“ ilustruje položaj ovih kompanija na svetskom tržištu na osnovu pisanja časopisa „Ekonomist“ i kaže: „Časopis Ekonomist je objavio da 5 preduzeća upravlja sa više od $50 \%$ svetskog tržišta u sledećim industrijama: u industriji trajnih potrošnih dobara, automobilskoj, elektroenergetskoj, elektronskoj i industriji čelika. Na osnovu istog izvora 5 firmi kontroliše preko $40 \%$ globalnog tržišta nafte, personalnih računara i medija“.

Ovaj trijumf neoliberalne strategije u svetu sa naglašenom tragičnom neokolonijalnom konotacijom proširio je danas zonu svog uticaja iz Latinske Amerike na Srednju i Istočnu Evropu. U ovom savremenom društvu na Zapadu u svetu globalizma novac je postao merilo svih vrednosti čoveka, države, svih vrednosti u društvu. Tako je „novac postao univerzalno sredstvo ne samo merenja ljudskih aktivnosti već i upravljanja tim istim aktivnostima kako u ekonomiji tako i u drugim sferama društvenog života“. 7

Dok se s jedne strane makroekonomska nacionalna politika fundira po interesima centara moći na Zapadu, s druge strane jedino zastupnici i zagovornici neoliberalnog projekta današnje stanje u svetskoj ekonomiji gledaju sa optimizmom. Njih ni intelektualno ni ljudski ne dotiče činjenica da danas u svetu postoje regioni i nacionalne države koji nemaju baš nikakve šanse da u bliskoj budućnosti privuku strane investicije i naprave radikalniji iskorak iz teške i besperspektivne ekonomske situacije u kojoj se nalaze.

\footnotetext{
${ }^{4}$ Sergej Kara-Murza, Manipulacija svešću, knj. 1, Beograd, Prevodilačka radionica Rosić: „Nikola Pašić“, 2008, str. 12.

${ }^{5}$ Momir Bulatović, Ekonomija i demokratija, Jumedia Mont, Podgorica, 2011, str. 40.

${ }^{6}$ Isto.

${ }^{7}$ Aleksandar Zinovjev, Zapad: fenomen zapadnjaštva, Beograd, Naš dom, 2002, str. 83.
} 
Poznatim starim entitetima država, nacija, nacionalna ekonomija, kultura, itd., svima se oduzimaju osnovni atributi suverenosti i odatle proistekla značenja i smisao. Više nije tajna, tj. primetno je propadanje nacionalne države u više etapa. Ovde se radi o preoblikovanju, izobličavanju i izopačavanju država, mogli bi reći da postoji dinamika i kontinuitet i da "to označava dinamičku i statičku, procesnu i strukturnu slabost“. ${ }^{8}$

S obzirom da se nacionalna država nalazi stalno na udaru globalizacije, ona je u permanentnoj krizi, a ovde više nije reč samo o malim i nemoćnim državama, možemo reći da na početku 21. veka kriza države postaje opšta pojava. Zbog toga građani sve više nisu lojalni sopstvenoj državi nego korporacijama, nevladinim organizacijama, etničkim i religioznim zajednicama.

Međunarodna podela rada sve više poprima intenzivan karakter što proizvodi duboku socijalnu i političku diferencijaciju. U ovim često sudbonosnim procesima veliki deo društva, pa čak i cele nacije ostaju na rubu ekonomskog razvoja i socijalnog beznađa bez ikakvih mogućnosti da se samostalno, tj. uz pomoć sopstvene države ikako izvuku iz nastale katastrofalne situacije, pogotovo ne u nekoj bliskoj budućnosti. ${ }^{9}$

S obzirom da se makroekonomska politika fundira po volji i interesima centara moći na Zapadu potpuno je slobodno kretanje iz razvijenih zemalja u zemlje u razvoju, čime se guši sopstvena nacionalna proizvodnja i zemlje dovode u finansijsku prezaduženost i neokolonijalno ropstvo. Ovaj trend globalno između bogatih i siromašnih zemalja se stalno rapidno uvećava.

Uzgred da se podsetimo da globalizacija ekonomije, ipak, nije bila moguća kada su uporedo i nezavisno funkcionisala dva sektora svetske privrede socijalistički i kapitalistički. U tim uslovima kapitalistički sistem je funkcionisao sa centralom i periferijom dok je u socijalističkom sistemu svaka država ponaosob pokušavala da izgradi samodovoljnu zatvorenu ekonomiju.

Kada je krajem prošlog veka kapitalistička privreda počela da dominira proces globalizacije je uzeo maha i više nisu birana sredstva i metode da se što više nastavi i razvije ovaj proces ekspanzije slobodnog kretanja kapitala. Globalizacija tako menja karakter nacionalnih ekonomija pa se one transformišu od relativno zatvorenih sistema u otvorene sisteme u podređene elemente neoliberalnog svetskog poretka. Ovi novi ekonomski tokovi ni malo ne doprinose razvoju slabih, pogotovo ne slobodnih nacionalnih ekonomija. Globalizacija vodi ka pretvaranju država u „šahovska polja“ gde su „polja“ bogate i siromašne oblasti. ${ }^{10} \mathrm{U}$ takvim uslovima se bogati krajevi, uglavnom, opredeljuju za globalnu ekonomiju i nastoje da zaobiđu sopstvenu državu, nacionalna država se tako dezintegriše ili čak potpuno raspada kao ekonomska zajednica.

Da napomenemo da ovi procesi nemaju mnogo veze više sa modernizacijom, jer je prava modernizacija jedino bila moguća dok je kao osnovni subjekat međunarodne ekonomije funkcionisala suverena nacionalna država. Nema sumnje da savremeni procesi globalizacije oduzimaju suverenost i nacionalnim ekonomijama i nacionalnim državama.

\footnotetext{
${ }^{8}$ Miloš Knežević, „Slabljenje, izobličenje i razaranje države“, u zborniku: (Dez)integracija država i identitet, (priredili: Zoran Milošević, Živojin Đurić), Institut za političke studije, Beograd, 2014, str. 177.

${ }^{9}$ Anastasija Mitrofanova Vladimirovna, „Kriza nacionalne države u epohi globalizacije“, Nacionalni interes, Institut za političke studije, Beograd, 2012, br. 1/2012, str. 12.

${ }^{10}$ Isto.
} 
Danas u svetu postoje čak celi regioni i nacionalne države koji nemaju ni najmanje šanse da u bliskoj perspektivi privuku strane investicije i naprave radikalni iskorak iz veoma teške ekonomske situacije u kojoj se nalaze. Kao retka eventualna alternativa izlaza iz globalističkog ćorsokaka često se pominje objedinjavanje teritorijalno bliskih i relativno slično razvijenih susednih država, mada ovaj proces sporo teče, a već nailazi na mnogobrojne blokade. Ne predstavlja nikakvu utehu, pogotovo putokaz izlaska iz krize činjenica da globalizacija nije baš uvek i potpuno pod kontrolom najmoćnijih finansijskih centara na Zapadu već se u određenim okolnostima javljaju depresivni regioni, koji vremenom postaju mesta političke nestabilnosti.

Više istorija globalizacije se ne pokazuje samo na tragičnom primeru latinoameričkog kontinenta, primećuje dr Momir Bulatović ${ }^{11}$ kao hronologija užasnog besmisla, surovosti i pljački i zaključuje: „Kada se sazna koliko je ljudi moralo da bude u zatvoru da bi cene bile slobodne. Koliko je otmica, mučenja i ubistava izvršeno kako bi kapital imao nesmetan protok“. ${ }^{12}$

Noam Čomski (Noam Chomsky) godinama u svetu jedan od vodećih intelektualaca nije slučajno poručio političkom i javnom mnjenju Srbije: „Srbija treba da uči od Latinske Amerike i da se okrene svojoj istoriji“. ${ }^{13}$ Uzgred, primećuje dr Momir Bulatović da je nemerljiva i nezaustavljiva volja naroda, koji živi na ovom kontinentu, da prekine pljačku njihovih država i da raščisti sa siromaštvom „koje ga prati kao neko davno prokletstvo“, i dalje nastavlja, kolika je mera desuverenizacije jedne nacionalne države danas pokazuje se i na primeru izbora, mada je MMF potpuno obesmislio izborni proces i volju građana još uvek nije dostavio i spisak zabranjenih pitanja, pitanja o kojima birači nemaju prava da odlučuju. ${ }^{14}$

Starim entitetima tj. državi, nacionalnoj ekonomiji, kulturi, itd u današnjim uslovima globalizacije ne oduzimaju se samo atributi suverenosti već ovi pojmovi gube svoja izvorna značenja i smisao. Tendencije prodora multinacionalnih kompanija uzele su u toj meri maha da čak nikakav pandan ni prepreku više ne predstavljaju ni vlade pojedinih najbogatijih i najmoćnijih država sveta. U savremenim procesima globalizacije oduzima se pravo svakoj nacionalnoj državi da unosi restrikcije i ograničenja na svom tržištu. Ukoliko bi ona (nacionalna država), ipak, po svojoj volji pokušala to da radi, prekršila bi Vašingtonski konsenzus i posebne sporazume u okviru STO-a. Sposobnost svake države da se zaštiti kako od spoljašnjeg tako i unutrašnjeg neprijatelja, pre svega, zavisi od njene državne moći, koja je limitirana nivoom i vrstama njene suverenosti. Nacionalna bezbednost ostaje jedan od najznačajnijih faktora opstanka svake države, ali u savremenim uslovima, u uslovima svetske globalizacije nacionalna bezbednost više uopšte ne predstavlja dovoljan uslov njenog opstanka. Nedostatkom njene realne moći, moći nacionalne države, najčešće se stvara stanje i uslovi za anarhiju i opštu kriminalizaciju društva, samim tim i za razaranje države iznutra. Korumpirane i podaničke vlade, smatramo da o tome ne treba posebno govoriti, predstavljaju veoma loše saveznike i njihovim narodima i državama.

Kraj 20. i početak 21. veka predstavljaju period renesanse geopolitike. Geopolitika je potpuno promenila sadržaj od vremena kada je švedski naučnik Rudolf Kjelel (Rudolf Kjelel) 1916. godine prvi put upotrebio ovaj termin kao naziv u njegovom radu „Država kao životni

\footnotetext{
${ }^{11}$ Momir Bulatović, nav. delo.

${ }^{12}$ Isto.

${ }^{13}$ Noam Čomski, Pečat, broj 150, Beograd, 2011.

${ }^{14}$ Momir Bulatović, nav. delo.
} 
oblik" i geopolitiku definisao kao nauku o državi kao geografskom organizmu ili pojavi u prostoru. ${ }^{15}$ Geopolitika je danas u toj meri promenila svoje izvorno značenje i smisao da ne predstavlja ništa drugo do imperijalni zamah subjekata globalne svetske moći, njihove nove ekspanzione planove, geopolitičke zavere (kriptopolitiku) i nadolazeća geopolitička žarišta.

Nikako ne treba da zaboravimo da su se upravo u vremenu prodora globalizacije dogodile mnogobrojne geografske - političke promene na balkanskom i južnoslovenskom tlu krajem prošloga veka. Naravno, geopolitička futurologija i stupa na scenu baš onda kada se državne granice dovode u pitanje, a zajedno sa njima i državna suverenost, $\mathrm{tj}$. kada ne samo pojedini državni i regionalni prostori već i celi kontinenti postaju predmet podložnosti prekrajanju i preoblikovanju.

Strategija (grčko poreklo reči stratos - vojska i agein - vođstvo), strategija imperijalnih centara moći na Zapadu više nikako ne prihvata izvorne demokratske principe, pogotovo autentične nacionalne demokratske otpore i političku diferencijaciju, ona je opterećena nasilnim monizmom, asimilacijom i hegemonizmom.

Desuverenizacija država i nepovoljan razvoj međunarodnih odnosa u svetu, ne samo da u savremenom periodu nisu zaobišli Balkan već su, naprotiv, kao retko u kom delu sveta to izrazili ovde. ${ }^{16}$ Svetski centri političke i finansijske moći na Zapadu kao da su proglasili Balkan isključivom sferom svog uticaja i shodno se tome ponašaju kao apsolutni gospodari. U vezi s tim da konstatujemo da kada se radi i o evrointegracijama, kontinuiranim pritiscima različite vrste je izložen srpski narod od koga se traži da prihvati baš sve diktate sa Zapada, sopstvenu denacifikaciju i gubitak svoje duhovne, kulturne, nacionalne i državne kolevke - Kosova i Metohije. ${ }^{17}$

Iz ovih i mnogih drugih razloga želimo da istaknemo da ne postoje samo apologete neoliberalnog modela globalizacije već i intelektualni i kolektivni subjekti, koji sve više sumnjaju i u globalističke istine i u njihove lidere. ${ }^{18}$

\section{Međunarodno pravo i novi i stari imperijalizam}

Apsurdnost i besmisao neoliberalnog projekta, projekta ostvarivanja strategije planetarne hegemonije manifestuje se u svoj punoći u međunarodnim odnosima u rušenju svih osnovnih vrednosti savremene države: suverenosti, teritorijalne celokupnosti, nezavisnosti, ustavnog poretka, istinskih ljudskih prava i sloboda, itd. Velike geopolitičke promene i njihove posledice koje su se baš u vremenu prodora neoliberalnog koncepta globalizacije desile na balkanskom i južnoslovenskom tlu i obrnuto, ovi dezintegrišući procesi trebali su da ostvare pretpostavke za dalji i dublji prodor neoliberalnog koncepta na balkanskom i južnoslovenskom tlu, bez obzira na žrtve i neviđena krvoprolića. Strategija teritorijalne ekspanzije, tj. strategija osvajanja novih životnih prostora morala je da se ostvari po svaku cenu, ona je bila strategija broj 1.

\footnotetext{
${ }^{15}$ Dušan Proroković, Geopolitika Srbije - Položaj i perspektive na početku XXI veka, Službeni glasnik, Geopolitika, Beograd, 2012.

${ }^{16}$ Jovo Marković, „Diplomatija i šah - Ni konfrontacija ni kapitulacija“, Nacionalni interes, 1/2012, Institut za političke studije, Beograd, 2012, str. 186.

${ }^{17}$ Isto, str. 187.

${ }^{18}$ Dž. R. Sol, Propast globalizma i preoblikovanje sveta, Arhipelag, Beograd, 2011, str. 299.
} 
Ne samo dvostruki već višestruki standardi su nova politička realnost, koja u ponašanju i delovanju ne proizvodi samo pustoš i krvoproliće već i sve veće razlike i diferencijaciju među samim ovim državama. Zbog toga savremeno međunarodno pravo bez svake sumnje postaje nepravo, tj. pravo tiranina na žrtvu. Ne treba smetnuti s uma da je kroz istoriju kriza svetske organizacije za mir i bezbednost upravo jedan od najvećih indikatora ne samo opšte krize u međunarodnim odnosima već i opasnosti od globalnih ratnih konflikata. Ovakvim i sličnim povodima asocirane su i reči ruskog predsednika Vladimira Putina: „govore nam da kršimo norme međunarodnog prava. Kao prvo, dobro je što su se setili da postoji međunarodno pravo i hvala im na tome - bolje ikad nego nikad... Znate ovo čak više nisu ni dupli standardi. Ovo je neki začuđujući primitivni i pravolinijski cinizam“. ${ }^{19}$

Istorija sveta, moramo da konstatujemo da je i do sada bila istorija različitih imperija. Imperije su postojale u Starom, Srednjem i Novom veku i sve su one imale period prosperiteta, razdoblje stabilizacije i neminovnu fazu propadanja. Zbog toga je značajno ukazati da pravi koreni savremene globalizacije, posebno globalizma, dosežu još u daleku prošlost u vremena pre nastanka Svetog rimskog i Franačkog carstva, mongolskog, turskog, habsburškog, britanskog, francuskog, danas američkog imperijalizma.

Mada među njima postoje značajne razlike kad je reč o istorijskim i društvenim okolnostima u kojima se nastajale, vremenskom periodu imperijalne dominacije i hegemonije, tehnološkom nivou i raznovrsnosti sredstava, koja su koristili za ostvarivanje svojih imperijalnih ciljeva. Vrednosti koje su zagovarale i nametale imaju nešto vrlo duboko i suštinski zajedničko i destruktivno. Kad je reč o strateškim planovima i ciljevima zajednička im je težnja ka ekspanziji i osvajanju, kao i strast za što dužim vremenskim periodom dominacije. Kada je reč o metodama i sredstvima za ostvarivanje imperijalnih interesa kao da se tu nije ništa bitnije promenilo. U stvari, radi se o primeni tehnološki dostignutih najsurovijih sredstava sile, pljačke i ubijanja. ${ }^{20}$ Stolećima su uništavana deca, žene, ljudi, narodi, države, regioni, kontinenti, cele civilizacije, planeta Zemlja, generalno sam život.

Danas nije samo reč o antidemokratskom kidisanju SAD na zemlje trećeg sveta već je „u pitanju plansko, sistematsko i intenzivno povećanje agresije čak na najbliže zapadne saradnike u Evropi“. ${ }^{21}$

Ovde želimo da istaknemo da ove države na Zapadu i pored velike političke, ekonomske i vojne moći nisu uspele da prevladaju separatističke dezintegracione tendencije, koje potiču iz ranijih vremena i postoje na njihovom državnom tlu: poput slučajeva Baskije, Severne Irske, Kvebeka, etnojezičke podele u Belgiji, poznati slučajevi Katalonije, Škotske, Korzike, domorodačke populacije Australije, SAD i Kanade, sve do najnovijih primera dezintegracionih tendencija Teksasa, Aljaske ili regiona Veneto u Italiji. $^{22}$

\footnotetext{
${ }^{19}$ Vladimir Putin, „Nato može da dolazi u Sevastopolj nama u goste, a ne mi njima“ (transkript celovitog govora ruskog predsednika, održanog 18. marta 2014. godine u Georgijevskoj dvorani u Kremlju, gde je prisustvovao kompletan sastav Saveta Federacije i Državne Dume, te prve ličnosti svih ruskih federalnih jedinica, ali i predsednik Državnog saveta Krima i krimski premijer), Radio gornji grad: Časopis za književnost $i$ kulturu u prijelomu epohe, 20. 03. 2014, htpp://radiogornjigrad.wordpress.com/2014/03/20/vladimir-putin-nato-da-dolazi-usevastopolj-nama-u-goste-a-ne-mi-njima/(22.03.2014).

${ }^{20}$ Đuro Bodrožić, " Globalizam i nacionalni suverenitet", Zoran Milošević, Živojin Đurić, priredili, (Dez)integracija država $i$ indentitet, Institut za političke studije, Beograd, 2014.

${ }^{21}$ Noam Čomski, Godina 501. konkvista se nastavlja, „Svetovi“, Novi Sad, 1998.

${ }^{22}$ Aleksandra Mirović, „Integracija i dezintegracija kao paralelni procesi savremene globalizacije“, u zborniku, (Dez)integracija država i identitet, (priredili: Zoran Milošević, Živojin Đurić), Institut za političke studije, Beograd, 2014, str. 89.
} 
Etničke i religiozne razlike ne proizvode uvek separatizam, ali se zato degradiranje državnog suvereniteta povratno manifestuje kroz etno-religiozne konflikte. U osnovi etnoreligijski faktor je sekundaran ako se uzmu u obzir ekonomski aspekti i stvarni uzroci problema.

Postoje dokumenta koja potvrđuju da je prvobitni cilj Džohara Dudajeva (Dzohar Dudajev) bila izgradnja svetovne čečenske države. Ustavom Čečenije iz 1992. godine bile su zagarantovane verske slobode da bi od posebnog značaja bilo odvajanje religijske organizacije od države. Na osnovu rečenog uzroke čečenskom secesionizmu ne treba tražiti u religiji i etnifikaciji već u ekonomiji.

Poznati naučnik i istraživač Mišel Čosudovski (Michael Chossudovsky) potpuno negira tezu popularnu na Zapadu da je građanski rat u Jugoslaviji na kraju 20. veka proistekao iz etno-kulturnih različitosti duboko ukorenjenih u tradiciji pojedinih naroda i smatra da je dezintegracija jugoslovenske države prevashodno uzrokovana ekonomskim faktorom. ${ }^{23} \mathrm{U}$ vezi s tim on podseća da je na ove konflikte suštinski uticao spoljni faktor programom makroekonomskog restruktuiranja nametnutog od stranih zajmodavaca, koji je doveo do dezintegracije industrijskog sektora i gubljenja socijalne sigurnosti i garancija.

Ovakvo zaključivanje potvrđuje i istraživanje uzroka genocida u Ruandi 1994, godine. $^{24}$ Njegovi rezultati istraživanja pokazuju da je krajnje simplifikovano i u osnovi netačno kada se na Zapadu želi da se taj događaj objasni međuplemenskom mržnjom i unutrašnjim uzrocima. Sama po sebi etnička napetost u stepenu u kojem je i ranije postojala ne bi mogla da izazove tako katastrofalne posledice.

Za razliku od shvatanja Mišela Čosudovskog da pomenemo kako postoji i druga grupa autora u svetu, kojima pripada francuski politikolog Paskal Bonifas (Pasqual Boniface), koji smatra da osnovne uzroke dezintegracije ne treba tražiti u socijalnom siromaštvu i u najsiromašnijim regionima države već tamo gde se nalazi bogatstvo i gde bogati regioni raspolažu finansijski vrednim resursima za integraciju u svetsku privredu. ${ }^{25}$

O tome kolika je danas koncentracija finansijske moći transnacionalnih korporacija na Zapadu dokazuje i ova opservacija dr Zorana Miloševića: „Prema rezultatima istraživanja Švajcarskog federalnog tehnološkog univerziteta $90 \%$ korporacijskog dohotka globalne ekonomije kroz različite forme slije se samo u 300 transnacionalnih korporacija, pri čemu $60 \%$ dohotka otpada na finansijske korporacije. ${ }^{26}$

Često se zaboravlja da su na kraju 20. veka u procesima agresije globalizacije, u stvari globalizma, razbijene tri moćne federacije jugoslovenska, čehoslovačka i sovjetska, jugoslovenska sa izrazito antisrpskom dimenzijom. ${ }^{27}$ Posmatrajući međunarodne odnose danas i analizirajući ono sve što se ranije dogodilo neophodno je biti svestan činjenice da se, ipak, strategija prodora na Istok ne može ostvariti samo transnacionalnim kompanijama ni isključivo nevladinim organizacijama niti jedino vojnim putem.

\footnotetext{
${ }^{23}$ Michael Chossudovsky, The Globalization of Poverty: Impacts of IMF and World Bank Reforms, London: Zed Books, 1997, p. 243-244.

24 Isto.

${ }^{25}$ Pasqual Boniface, „The Proliferation of States“, The Washington Quarterly, 1998, Summer, p. 117.

${ }^{26}$ Zoran Milošević, „Transnacionalne korporacije i država“ u zborniku radova, (Dez)integracija država i identitet, (priredili: Zoran Milošević, Živojin Đurić), Institut za političke studije, Beograd, 2014, str. 101.

${ }^{27}$ Aleksandar Dugin, Oprostite nam, Srbi u jeku vašeg rata mi smo čvrsto spavali („Pečat“, razgovor vodila Biljana Živković, prev. Sava Rosić), „Novi standard“, 21. mart 2014, htpp://www.standard.rs/index.php/politika28716-\%d0\%b0\%, (31/03/2014).
} 
Na jugoslovenskom primeru dr Aleksandar Savanović pokazuje da je Džordž Soroš jedan od u svetu glavnih zagovornika ideje, ideologije i političke prakse „otvorenog društva“. U periodu od 1994. do 2007. godine ova fondacija je utrošila 330 miliona dolara na promociju mira, tolerancije, vladavine prava, nezavisnosti medija, ljudskih prava i demokratskih vrednosti. ${ }^{28}$ Uopšte uzev, ova fondacija je bila direktno uključena u obaranje srpskog režima i u tu svrhu finansirala „antirežimske strukture u državi na različitim nivoima i u različitim aspektima od medija: JUTEL, Vreme, Radija B92, Monitor iz Crne Gore i plejadu nezavisnih intelektualaca“, pojedine opozicione stranke pre svega G 17 Plus, Liberalno-demokratsku partiju, studentsku organizaciju Otpor u finansijskom i logističkom smislu, itd. ${ }^{29}$

\section{Srpski primer}

Celokupni savremeni ustavno-pravni razvoj Srbije moguće je podeliti na dva perioda. Prvi obuhvata vreme od legalizovanja višepartijskog sistema 1990. do 2000. godine dok drugi obuhvata vreme od oktobarskih promena do danas. U osnovne karakteristike prvog perioda spadaju konsolidacija novouspostavljenog višepartijskog sistema, kontinuirani raspon između vladajućih i opozicionih političkih partija i političkih snaga u pristupu strateškim pitanjima zemlje, izuzetno teške ekonomske i socijalne prilike, vreme međunarodnih izolacija i blokada, dezintegracija zajedničke jugoslovenske države, građanski rat, intervencija vojne alijanse NATO 1999. godine i drugo.

Period posle oktobarskih promena obeležava dezintegracija dvočlane federacije SRJ, dominantna i neobjektivna uloga međunarodne zajednice u procesu ilegalnog proglašenja nezavisne države Kosovo na teritoriji Autonomne pokrajine Kosovo i Metohija u Srbiji, državna i ekonomska desuverenizacija Srbije i u vezi s tim prodor međunarodnih subjekata globalizacije na srpsko državno tle.

Nove vlasti u Srbiji posle oktobarskih promena srpskom narodu su euforično nudile viziju savremene i demokratske Srbije potpuno oslonjene na Zapad. Svoju tvrdnju su zasnivale na neoklasičnim ekonomskim teorijama, ekonomskoj šok-terapiji i politici Vašingtonskog konsenzusa. To je učinjeno uprkos tome što su upozoravane, a prethodna iskustva pojedinih zemalja nedvosmisleno pokazala da Vašingtonski konsenzus ne predstavlja ništa drugo do projekat ekonomske neokolonizacije sastavljen u interesu krupnog finansijskog kapitala, tj. transnacionalnih kompanija, kojim se u siromašnim zemljama modelira politički, ekonomski, medijski prosto podređen međunarodnim ekonomskim i političkim interesima. Program je razrađen od strane MMF-a, Svetske banke i administracije SAD - Ministarstva finansija i USAID-a, a osnovni su mu elementi stabilizacija, liberalizacija i privatizacija. Stabilizacija je značila stabilan, ali precenjen kurs dinara, radikalnom liberalizacijom carinske stope su bile smanjene, a ukinuta sva vancarinska ograničenja. Ovakav proces stabilizacije i liberalizacije proizveo je mnogobrojne negativne posledice za srpsko društvo, između ostalog, doveo do gušenja domaće proizvodnje i enormnog pada cena vrednosti domaćih preduzeća na svetskom tržištu. Tako je obezvređen i po iz-

\footnotetext{
${ }^{28}$ Aleksandar Savanović, Džordž Soroš „Otvoreno društvo“ kao ideja, ideologija i politička praksa, Banja Luka, Fakultet političkih nauka, 2014.

${ }^{29}$ Isto.
} 
uzetno niskim prodajnim cenama u uslovima obavezne i masovne privatizacije prodat najvredniji i najatraktivniji deo državne (društvene) imovine, da bi i pored toga ekonomska prezaduženost zemlje bila višestruko uvećana. ${ }^{30}$

Desuverenizacija države u veoma značajnom delu provodila se i pravnim instrumentima. Proces donošenja najznačajnijih pravnih akata (ustava i ustavnih zakona) pratio je proces prenošenja nadležnosti sa viših na niže pravne instance i desuverenizacije zemlje sa slabljenjem centralnih organa vlasti. ${ }^{31}$

\section{Opšte dileme}

Još pre više od 20 vekova veliki grčki filozof Aristotel smatrao je da državna uređenja propadaju ili zbog unutrašnjih ili zbog spoljašnjih razloga. Aristotel je pisao da tiranija uvek počiva na nepravdi i nestabilnosti država i društva. Kada je govorio o revolucijama (ustancima) verovatno nije ni pretpostavljao da će na početku 21. veka na svetskoj političkoj sceni dominirati revolucije odozgo, tzv. „obojene revolucije“. ${ }^{32}$ Obojene revolucije ili revolucije boja postale su sinonim za geopolitičke promene u zemljama Jugoistočne Evrope, tj. u zemljama Evroazije u kojima je od 2000. do 2014. godine, uz logistiku i podršku SAD, došlo do promene političkih režima sa argumentacijom da su autoritarni, a njihove političke elite zamenjene liberalno-demokratskim prozapadnim političkim elitama.

Veoma često se prvom narandžastom revolucijom smatraju političke oktobarske promene u Beogradu 2000. godine, da bi se pod obojenim revolucijama u užem smislu podrazumevali događaji na područjima bivšeg SSSR-a, revolucija ruža u Gruziji 2003, narandžasta revolucija u Ukrajini 2004-2005. i 2014. godine, revolucija tulipana u Kirgistanu 2005. godine.

U svojoj suštini obojene revolucionarne promene su sastavni deo savremene geopolitike i radikalnog prekomponovanja savremenih međunarodnih odnosa. Obojene revolucije, u stvari, predstavljaju složen savremen geopolitički fenomen i tu objektivno, naučno nema mesta bilo kakvoj mistifikaciji. Sa aspekta savremene nauke one se ne mogu nazivati revolucijama samo zato što se pokreću i organizuju u Vašingtonu ili Briselu ili zbog toga što su masovne i populističke. Po svojim osnovnim svojstvima ove revolucije protivreče i poreklu i samoj suštini pojma socijalne revolucije.

U ovim novim obojenim revolucionarnim procesima spoljna podrška odabranim režimima i političkim grupama nije bila slučajna niti proizvoljna, jer su se planovi za ovakve političke promene vršili sistematski i pripadaju savremenim metodima specijalnog ratovanja kao sastavnom i bitnom elementu strategije imperijalne ekspanzije. U ovim kvazi revolucionarnim dešavanjima u navedenim zemljama težište aktivnosti bilo je usmereno ka političkim partijama i višestranačkim izborima, što znači blokadi političkih sistema, čime se, u stvari, stvarao prostor za aktivnosti zavođenja i manipulisanja širokim narodnim masama. Uvek je postojao inicijator i pokretač ovih promena, postojala je logistika i fi-

\footnotetext{
${ }^{30}$ Momir Bulatović, nav. delo.

${ }^{31}$ Vladan Stanković, „Načini desuverenizacije savremenih država/nacija. Politički, pravni, ekonomski i društveni pristup“, u zborniku (Dez)integracija država i indentitet, (priredili: Zoran Milošević, Živojin Đurić), Institut za političke studije, Beograd, 2014, str. 57.

${ }^{32}$ Miloš Đurić, Istorija antičke filozofije, Službeni glasnik, Pravni fakultet, Beograd, 2009.
} 
nansijska podrška iz inostranstva posebno kad se radi o opozicionim političkim liderima i partijama i nevladinim organizacijama i pokretima. ${ }^{33}$

Vlast se u novim uslovima veoma brzo seli na ulice, a započeti procesi prerastaju u sve veće nerede, jer planirana opozicija mora biti novi pobednik nezavisno od stvarnih rezultata na biračkim mestima. Tako zapadna demokratija utire put daljem progresu u svetu, a ne faktičkom gaženju suverenosti država i geopolitičkim planovima o otimanju prirodnih nacionalnih resursa. Naravno, metode i tehnike izvođenja obojenih revolucija uvek su prilagođene specifičnostima svakog konkretnog geopolitičkog ambijenta, ali se i stalno dalje usavršavaju. Pored toga, veliki broj naučnika - istraživača ne bez razloga i utemeljenja bavi se komparativnom kvalitativnom i kvantitativnom analizom odnosa između obojenih revolucija i „arapskog proleća“, tzv. novih izvedenih revolucije, koje su, uglavnom, po istom modelu zahvatile zemlje Afrike i Bliskog istoka.

Ne potkupljuju se samo političke elite već globalizacija nastoji da prodre u samu dušu naroda i njome ovlada. Proces globalizacije u toj meri zahvatio je sve sfere života, njegove glavne ekonomske i političke aktere, mada novi globalni autoritet, ipak, nije uspostavljen. U novom svetskom poretku globalistički lider nije uspeo da se nametne kao neosporni lider sveta. Na otvorenoj svetskoj političkoj sceni nastupaju i nedržavni akteri sa najrazličitijim scenama „civilnog društva“. ${ }^{34}$

$U$ istom naučnom delu ovaj naš poznati profesor ustavnog prava i međunarodnih odnosa i spoljne politike ističe da se kritične tačke u raspravi o budućem svetskom poretku u stvari svode na nekoliko osnovnih pitanja: 1) da li je nova forma korporativnog kapitalizma zahvatila svet u celini u kome je nestalo podele na međunarodnu i unutrašnju sferu država; 2) da li će država kao osnovni subjekt međunarodne zajednice opstati ili će svoje mesto ustupiti globalnom civilnom društvu; 3) da li će geopolitika ustupiti mesto geoekonomiji; 4) da li nevladine organizacije mogu postati supstitut države ili samo njena protivteža; 5) da li su aktivisti nevladinih organizacija vrhunski humanitarni radnici i nove diplomate i propagandisti razvoja; i na kraju 6) da li civilno društvo i nevladin sektor treba gledati kao na embrion iz kojeg će proizaći novi globalni autoritet ili samo kako ona kaže „je u pitanju utopijska šema sa mračnom pozadinom“. ${ }^{35}$ Pri tome ona zaključuje da je ove aktere savremenih političkih odnosa potrebno ozbiljno i brižljivo analizirati ne samo u pogledu njihove strukture i funkcije nego, pre svega, u pogledu ideološke matrice na kojoj deluju.

Tako se stvara utisak da dolazi nova vladavina bez vlade, a to je samo, smatra akademik Kosta Čavoški, privid pošto država i dalje vlada, ali na ovaj način sa znatno smanjenom odgovornošću pred svojom javnošću i narodom.

\section{Zaključak}

I u nauci i u publicistici se još uvek ne pravi dovoljna razlika u značenju pojmova globalizacija i globalizam. Globalizacija je zakonomeran proces ekonomskog, finansijskog, informativnog, tehnološkog, kulturnog i drugog povezivanja ljudi dok se globalizam prevashod-

\footnotetext{
${ }^{33}$ Goran Budžak, Jovo Marković, „Naručene i planirane geopolitičke revolucije“, Balkanske sinteze, 3/2017, Filozofski fakultet, Niš, 2017, str. 83.

${ }^{34}$ Smilja Avramov, Civilno društvo i nevladine organizacije - Alternativni modeli svetske zajednice, Nova Evropa, Beograd, 2006.

${ }^{35}$ Isto.
} 
no svodi na novi totalitarizam i hegemonizam. I danas u integracionim procesima u svetu globalizam je odneo prevagu nad globalizacijom i zbog toga se nacionalne države i nacionalne ekonomije nalaze u permanentnoj krizi, pre svega krizi suverenosti. Naravno, i novim moćnim svetskim finansijskim oligarhijama smetaju nacionalne ekonomije i države zato što sputavaju protok međunarodnog finansijskog kapitala. Međutim, mnogi indikatori u međunarodnim odnosima, ipak, ukazuju da ovim entitetima u međunarodnim odnosima još uvek nije mesto u muzejima starina. lako ih čekaju mnogobrojna iskušenja i izazovi sa sigurnošću možemo reći da plan o formiranju svetske vlade i svetske države sa centrom u Vašingtonu na sadašnjem stupnju razvoja civilizacije predstavlja samo globalističku utopiju.

Ukoliko naučno analiziramo savremeno stanje neoliberalnog kapitalizma i procesa globalizacije danas u svetu, njihove glavne promotere i stožere, bitne elemente njihove strukture, način njihovog funkcionisanja i efekte delovanja, zaključujemo da je reč o ničemu drugom do o savremenom imperijalizmu u njegovoj silaznoj putanji. I pored velike halabuke na kraju 20. veka u zemljama tranzicije oko pravne države, jer se nacionalna država u uslovima globalizacije našla na posebno velikim iskušenjima i ona je u novim uslovima napadnuta odozgo i iznutra tako da gubi sopstvenu suverenost, njoj još, ipak, ne pripada mesto u muzeju starina. U globalističkoj agresiji na nacionalnu državu ruše se sve osnovne njene vrednosti: suverenost, teritorijalna celokupnost, nezavisnost, ustavni poredak, ljudska prava i slobode. $\mathrm{Na}$ talasima globalizacije velike geopolitičke promene i njihove posledice desile su se na kraju 20. veka baš na balkanskom i južnoslovenskom tlu, a one bi međunarodnu javnost trebalo da upozoravaju o mogućim novim međunarodnim izazovima i krvoprolićima. Geopolitika kao nauka se još od svog nastanka početkom 20. veka tematski bavi analizama vrednosti, nedostataka i ograničenja geografskog prostora, ali danas, pre svega, starim - novim planovima teritorijalne ekspanzije i strategije osvajanja novih životnih prostora.

\section{Literatura}

[1] Apter D. E., „Political systems and Development Change“, in: R. T. Hold and J. E. Turner eds. The Methodology of Comparative Research, New York: The Free Press, 1970.

[2] Avramov Smilja, Civilno društvo i nevladine organizacije - Alternativni modeli svetske zajednice, „Nova Evropa“, Beograd, 2006.

[3] Bodrožić Đuro, „Globalizam i nacionalni suverenitet“, u zborniku (Dez)integracija država $i$ identitet, (priredili: Milošević Zoran, Đurić Živojin), Institut za političke studije, Beograd, 2014, str. 13-33.

[4] Boniface Pasqual, ,,The Proliferation of States“, The Washington Quarterly, 1998, Summer, p. 117.

[5] Bulatović Momir, Ekonomija i demokratija, „Jumedia Mont“, Podgorica, 2011.

[6] Budžak Goran, Marković Jovo, „Naručene i planirane geopolitičke revolucije“, Balkanske sinteze, 3/2017, Filozofski fakultet, Niš, 2017, str. 79-87.

[7] Vladimirovna Mitrofanova Anastasija, „Kriza nacionalne države u epohi globalizacije“, Nacionalni interes, 1/2012, Institut za političke studije, Beograd, 2012, str. 9-28.

[8] Weiner M., Modernization, New York, London: Basic Books, pp. 3.

[9] Dugin Aleksandar, Oprostite nam, Srbi, u jeku vašeg rata mi smo čvrsto spavali, („Pečat“, razgovor vodila Biljana Živković, prev. Sava Rosić), „Novi standard“, 21. mart 2014, Internet, htpp://www.standard.rs/index.php/politika28716-\%d0\%b0\%, 31/03/2014.

[10] Đurić Miloš, Istorija antičke filozofije, „Službeni glasnik“, Pravni fakultet, Beograd, 2009.

[11] Zinovjev Aleksandar, Zapad: fenomen zapadnjaštva, Beograd, „Naš dom“, 2002. 
[12] Kara-Murza Sergej, Manipulacija svešću, knj. 1, Beograd, „Prevodilačka radionica Rosić“: „Nikola Pašić“, 2008.

[13] Knežević Miloš, „Slabljenje, izobličenje i razaranje države“, u zborniku, (Dez)integracija država i identitet, (priredili: Milošević Zoran, Đurić Živojin), Institut za političke studije, Beograd, 2014, str. 177-222.

[14] Marković Jovo, „Diplomatija i šah - Ni konfrontacija ni kapitulacija“, Nacionalni interes, 1/2012, Institut za političke studije, Beograd, 2012, str. 182-187.

[15] Milošević Zoran, „Transnacionalne korporacije i država“, u zborniku radova Dez)integracija država i identitet, (priredili: Milošević Zoran, Đurić Živojin, Institut za političke studije, Beograd, 2014, str. 101-113.

[16] Mirović Aleksandra, „Integracija i dezintegracija kao paralelni procesi savremene globalizacije“, u zborniku radova (Dez)integracija država i identitet, (priredili: Milošević Zoran, Đurić Živojin), Institut za političke studije, Beograd, 2014, str. 67-100.

[17] Proroković Dušan, Geopolitika Srbije - Položaj i perspektive na početku XXI veka, „Službeni glasnik“, „Geopolitika“, Beograd, 2012.

[18] Putin Vladimir, „Nato može da dolazi u Sevastopolj nama u goste, a ne mi njima“, Radio gornji grad: Časopis za književnost i kulturu u prijelomu epohe, 20.03.2014, htpp://radiogornji grad.wordpress.com/2014/0320/vladimir-putin-nato-da-dolazi-u-sevastopolj-nama-u-goste-a-ne-minjima/ (22.03.2014).

[19] Savanović A, Džordž Soroš „Otvoreno društvo,kao ideja, ideologija i politička praksa, Fakultet političkih nauka, Banja Luka, 2014.

[20] Sol Dž. R., Propast globalizma i preoblikovanje sveta, „Arhipelag“, Beograd, 2011.

[21] Stanković Vladan, „Načini desuverenizacije savremenih država/nacija. Politički, pravni, ekonomski i društveni pristup", u zborniku radova (Dez)integracija država i identitet, (priredili: Milošević Zoran, Đurić Živojin, Institut za političke studije, Beograd, 2014, str. 53-66.

[22] Chossudovsky Michael, The Globalization of Powerty: Impacts of IMF and World Bank Reforms, London: Zed Books, 1997, p. 243-244.

[23] Čomski Noam, „Pečat“, broj 150, Beograd, 2011.

[24] Čomski Noam, Godina 501, konkvista se nastavlja, „Svetovi“, Novi Sad, 1998. 